\title{
О ксилографическом сборнике буддийских текстов на монгольском языке из Национального музея Тувы"
}

\author{
Деляи Н. Музраева \\ Калмыцкий научный центр Российской академии наук, Российская Федерация, \\ Рита П. Сумба \\ Национальный музей им. Алдан Маадыр Республики Тыва, Российская Федерация
}
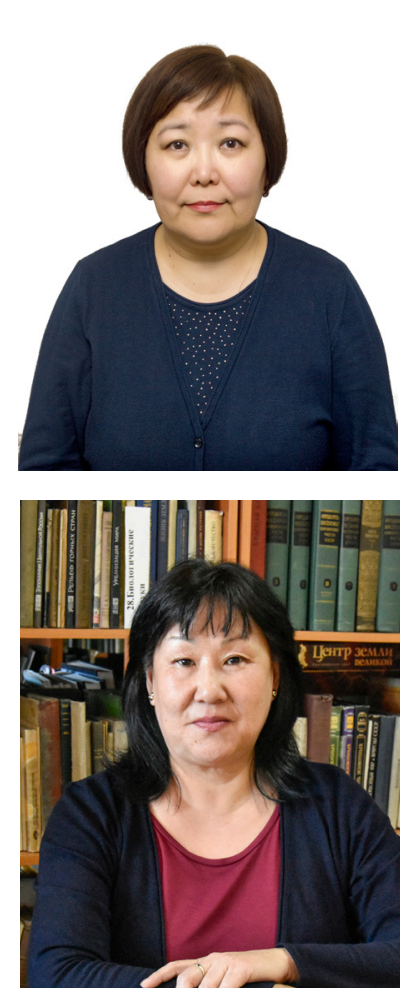

Статья вводит в научный оборот сборник буддийских текстов в транслитерации и переводе на русский язык из собрания Национального музея Республики Тыва. Он представляет собой довольно редкое издание ксилографического сборника на монгольском языке (шифр М-143). В нем насчитывается 11 листов малого формата. Сборник состоит из кратких извлечений из таких сочинений, как "Лхантаб», Сутра пробуждения почитания идама (уі dam), «Субхашита» Сакья-пандиты, наставления Джанджа-хутухты Ролби-Дорджэ и Ёндзин Еще Джалцана.

Известный российский монголовед А. Г. Сазыкин при описании монгольской коллекции музея отмечал наличие в ней бурятских изданий. Одним из таких образцов является ксилографический сборник о соблюдении буддийских обетов, который ему не доводилось встречать ранее. Его особенностью является то, что в нем принята иная система постановки диакритических знаков, чем в традиционных монгольских ксилографах. Так, диакритические знаки в виде двух точек, указывающие на согласную $\gamma$, в данном печатном издании указывают на согласную q.

Компоновка этого сборника свидетельствует о высокой эрудиции его составителя. Хотя его имя эксплицитно не указано в тексте, имеется лишь косвенное указание на то, что текст составлен не одним пишущим, а при участии кого-то еще.

Рассмотренный сборник позволяет пролить свет на принципы использования известных сочинений при разъяснении положений буддийской доктрины. То, что в тексте присутствует апелляция к верующим из числа светских последователей Учения Будды, демонстрирует значимость этой сферы проповеднической деятельности, практики буддийских священнослужителей в тувинской среде.

Ключевые слова: буддизм; письменный источник; музей; Тува; ксилографический сборник; монгольский язык; перевод; Лхантаб; Сакья-пандита; Субхашита; Джанджа-хутух$m a$

"Исследование проведено в рамках государственной субсидии - проект «Устное и письменное наследие монгольских народов России, Монголии и Китая: трансграничные традиции и взаимодействия» (регистрационный номер АААA-А19-119011490036-1).

\section{Для циитирования:}

Музраева Д. Н., Сумба Р. П. О ксилографическом сборнике буддийских текстов на монгольском языке из Национального музея Тувы [Электронный ресурс] // Новые исследования Тувы. 2019, № 2. URL: https://nit.tuva.asia/nit/ article/view/852 (дата обращения: дд.мм.гг.). DOI: 10.25178/nit.2019.2.12

Музраева Деляш Николаевна - кандидат филологических наук, доцент, ведущий научный сотрудник, заведующий отделом монгольской филологии Калмыцкий научный центр Российской академии наук. Адрес: 358000, Россия, г. Элиста, ул. И. К. Илишкина, д. 8. Тел.: +7 (917) 680-80-21. Эл. адрес: deliash@mail.ru ORCID ID: 0000-0002-8619-9369 Сумба Рита Петровна - научный сотрудник отдела культуры, искусства и религии Национального музея им. Алдан-Маадыр Республики Тыва. Адрес: 667000, Россия, г. Кызыл, ул. Титова, д. 30. Тел.: +7 (923) 384-32-91. Эл. адрес: risu1232001@yahoo.de Muzraeva Delyash Nikolaevna, Candidate of Philology, Leading Research Fellow and Head, Department of Mongolian Philology, Kalmyk Scientific Center, Russian Academy of Sciences. Postal address: 8 Ilishkin St., 358000 Elista, Russian Federation. Tel.: +7 (917) 680-80-21.E-mail: deliash@mail.ru

Sumba Rita Petrovna, Research Fellow, Department of Culture, Science and Religion, Aldan-Maadyr National Museum of the Republic of Tuva. Postal address: 30 Titov St., 667000 Kyzyl, Russian Federation. Tel.: +7 (923) 384-32-91. E-mail: risu1232001@yahoo.de 


\title{
On a xylographic compilation of Buddhist texts in Mongolian language from the National Museum of the Republic of Tuva"
}

\author{
Delyash N. Muzraeva \\ Kalmyk Scientific Center of the Russian Academy of Sciences, Russian Federation, \\ Rita P. Sumba \\ Aldan-Maadyr National Museum of the Republic of Tuva, Russian Federation
}

\begin{abstract}
This publication discusses a woodcut compilation of Buddhist texts from the collection of the National Museum of the Republic of Tuva, also providing a transliteration and Russian translation of the text. This woodcut collection in Mongolian (code M-143) is a rather rare edition. It has 11 sheets of small format and consists of short extracts from such works as the "Lhantab", "The Awakening Sutra of the worship of Yidam (yi dam)", "Subhashita" by Sakya Pandita, the teachings of Janja-Khutuhta RolbyDorje (lcang skya rol ba'i rdo rje) and Yonjin Yeshe Dzhaltsana (yongs 'dzin ye shes rgyal mtshan).

A well-known Mongolian researcher A. G. Sazykin, when describing the Mongolian collection of the Museum, noted the presence of Buryat publications in it. One such sample is a woodcut compilation of the observance of Buddhist vows (M-143), which he had never seen before. The peculiarity of this woodblock is that it adopts a system for placing diacritical marks which differs from that in traditional Mongolian woodblock prints. Thus, diacritical marks in the form of two points, indicating the consonant $\gamma$, here indicate the consonant $q$.

The layout of this collection demonstrates the high erudition of its compiler. Although his name is not explicitly mentioned in the text, there is only an indirect indication that the text was put together by several, rather than one, compilers.

The text allows us to shed some light on the principles of the use of well-known writings in explaining the provisions of the Buddhist doctrine. The fact that the text contains an appeal to believers from among the secular followers of the Buddha's teaching demonstrates the importance of this field of preaching, practised by Buddhist clergy among Tuvans.
\end{abstract}

Keywords: Buddhism; written source;museum; xylographic compilations; Mongolian woodblock print; Mongolian language; Lhantab; Sakya Pandita; Subhashita; lcang skya rol ba'i rdo rje

\footnotetext{
"The study was carried out within the framework of state subsidies - the project "Oral and Written Heritage of the Mongolian Peoples of Russia, Mongolia and China: Cross-Border Traditions and Interactions” (registration number AAAA-A19-119011490036-1).

\section{For citation:}

Muzraeva D. N. and Sumba R. P. On a xylographic compilation of Buddhist texts in Mongolian language from the National Museum of the Republic of Tuva. The New Research of Tuva, 2019, no. 2 [online] Available at: https:/nit.tuva. asia/nit/article/view/852 (access date: ...). DOI: 10.25178/nit.2019.2.12
}

\section{Введение}

Буддизм является важной составной частью духовной культуры народов Азии, в том числе проживающих в России - калмыков, тувинцев, бурят. Об этом можно судить по тем письменным источникам, которые сохранились в архивных и музейных фондах и книгохранилищах (Музраева, 2011; Мирзаева, 2018), частных коллекциях (Корнеев, 2016), а также по образцам фольклора, в основу которых были положены сочинения средневековой тибето-монгольской историографии (Донгак, 2018). Именно они позволяют исследователям составить представление о текстах, имевших хождение в среде лам и светских верующих, по ним можно реконструировать систему взглядов, философских концепций, обрядовую религиозную жизнь буддистов, каким божествам они поклонялись, какие обряды совершались в их честь, каких иерархов почитали и т. д.

Одно из интересных собраний восточных книг находится в Национальном музее им. Алдан-Маадыр Республики Тыва. Коллекция музея включает письменные источники преимущественно на тибетском и монгольском языках, есть небольшое количество текстов на ойратском языке (см.: Sazykin, 1996: 44; Бичелдей, 2011: 230).

В данной публикации мы даем описание, транслитерацию и перевод одного из интереснейших образцов буддийских печатных текстов на старописьменном монгольском языке, хранящихся в фонде 
Национального музея Республики Тыва, тем самым вводя в научный оборот. Наш интерес к нему был вызван отчасти той характеристикой, которую дал этому памятнику А. Г. Сазыкин при описании монгольской коллекции музея. Он отметил, что в музейной коллекции имеются бурятские ксилографы. Одним из таких образцов является ксилографический сборник о соблюдении буддийских обетов, который ему не доводилось встречать ранее (Sazykin, 1996: 45). Он также отметил, что в данном ксилографе (шифр М-143) отсутствует титульный лист, соответственно, не определено общее название сборника (там же: 45). Поскольку в ксилографе нет колофона (послесловия), в котором оно могло быть зафиксировано, и в котором могло быть указание на место издания, мы определяем его как ксилографический сборник на старописьменном монгольском языке, изданный в одном из бурятских дацанов.

\section{Описание ксилографа М-143}

Рассматриваемый сборник сравнительно небольшой по объему. В нем насчитывается 11 листов малого формата. Текст отпечатан на бумаге русского образца. Имеется рамка, сделанная в две линии. Печати отсутствуют. Пагинация полистная, монгольскими словами слева на полях вне рамки. На каждой странице по 15 строк текста.

Особенностью данного ксилографа является то, что в нем принята иная система постановки диакритических знаков, чем в традиционных монгольских ксилографах. Так, диакритические знаки в виде двух точек, указывающие на согласную $\gamma$, которые обычно ставятся напротив указанной графемы слева от основной вертикальной линии, в данном печатном издании указывают на согласную $q$ в твердорядных словах (слогах) и согласную $k$ в слогах $k e, k i, k \ddot{u}$.

Примечательно, что в тексте отдельные имена и термины дублируются тибетскими эквивалентами, вписанными слева от поясняемого фрагмента текста или слова. Эти тибетские параллели мы приводим в тексте транслитерации, представленной далее, в фигурных скобках \{\}. В тех случаях, когда в тексте перевода мы вводим поясняющее слово, мы берем его в квадратные скобки []. Варианты переводов слов, словосочетаний указаны в тексте перевода в круглых скобках.

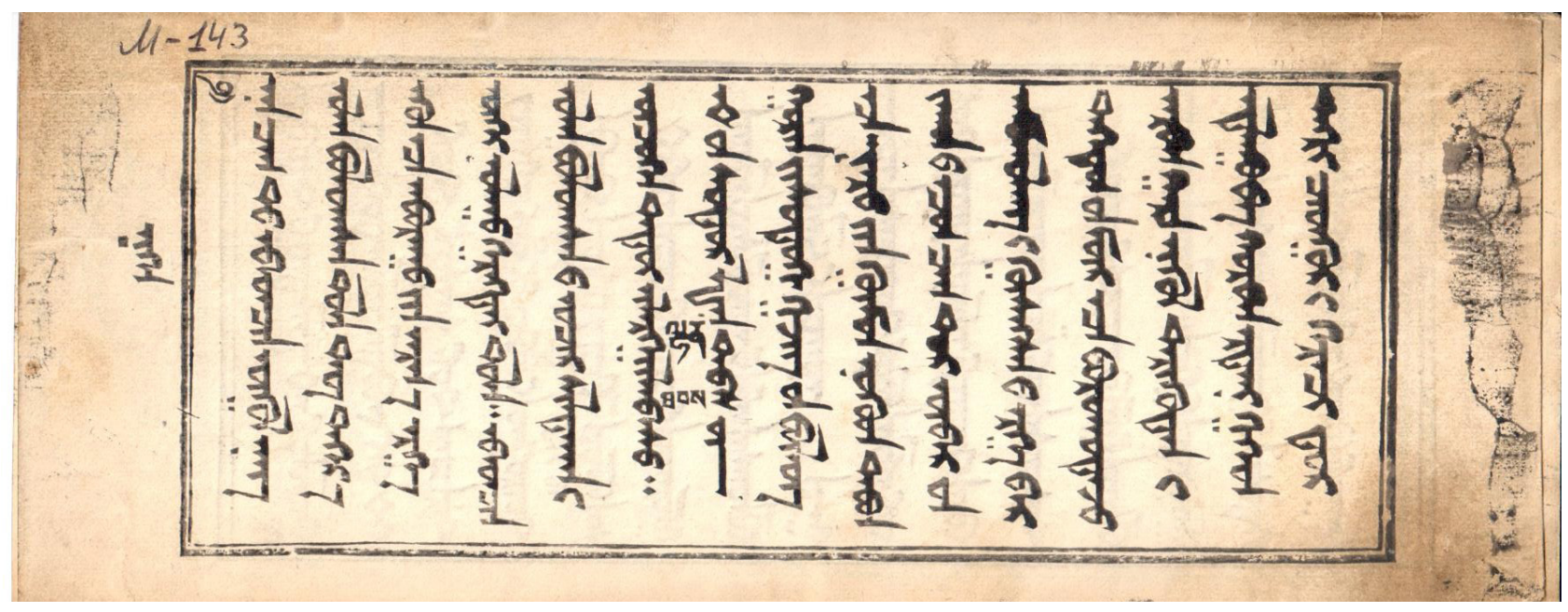

Фото 1. Фотокопия листа 1а ксилографа M-143.

Photo 1. A photocopy of page 1 a of xylograph $M-143$.

\section{Структура и содержание}

Относительно содержания этого сборника можно указать на такие его составные фрагменты, как:

1) Em-ün sudur Lhan-tabs-un qorin yisüdüki kiǰig-ün bölög-eče ('Из 29 й главы «О простудных болезнях» медицинской сутры (лечебника) Лхантаб’).

2) Idam bisilyaqu-yin egüskel-ün ǰerge-yin sudur-ača ('Из сутры пробуждения почитания идама (поклонения идаму)').

3) Saskya-yin sayin nomlal-ača ('Из наставлений (назидательных речений, поучений) Сакья-пандиты' или из «Субхашиты»).

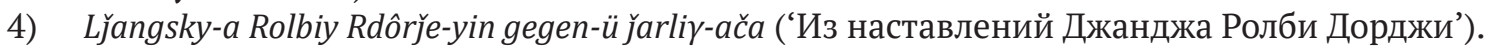

5) Yônga-gǰin Yišis Rgyalmčan-u gegen-eče ('Из [разъяснений] сиятельного Ёндзин Еше Джалцана'). 


\section{НОВЫЕ ИССЛЕДОВАНИЯ ТУВЫ}

www.nit.tuva.asia

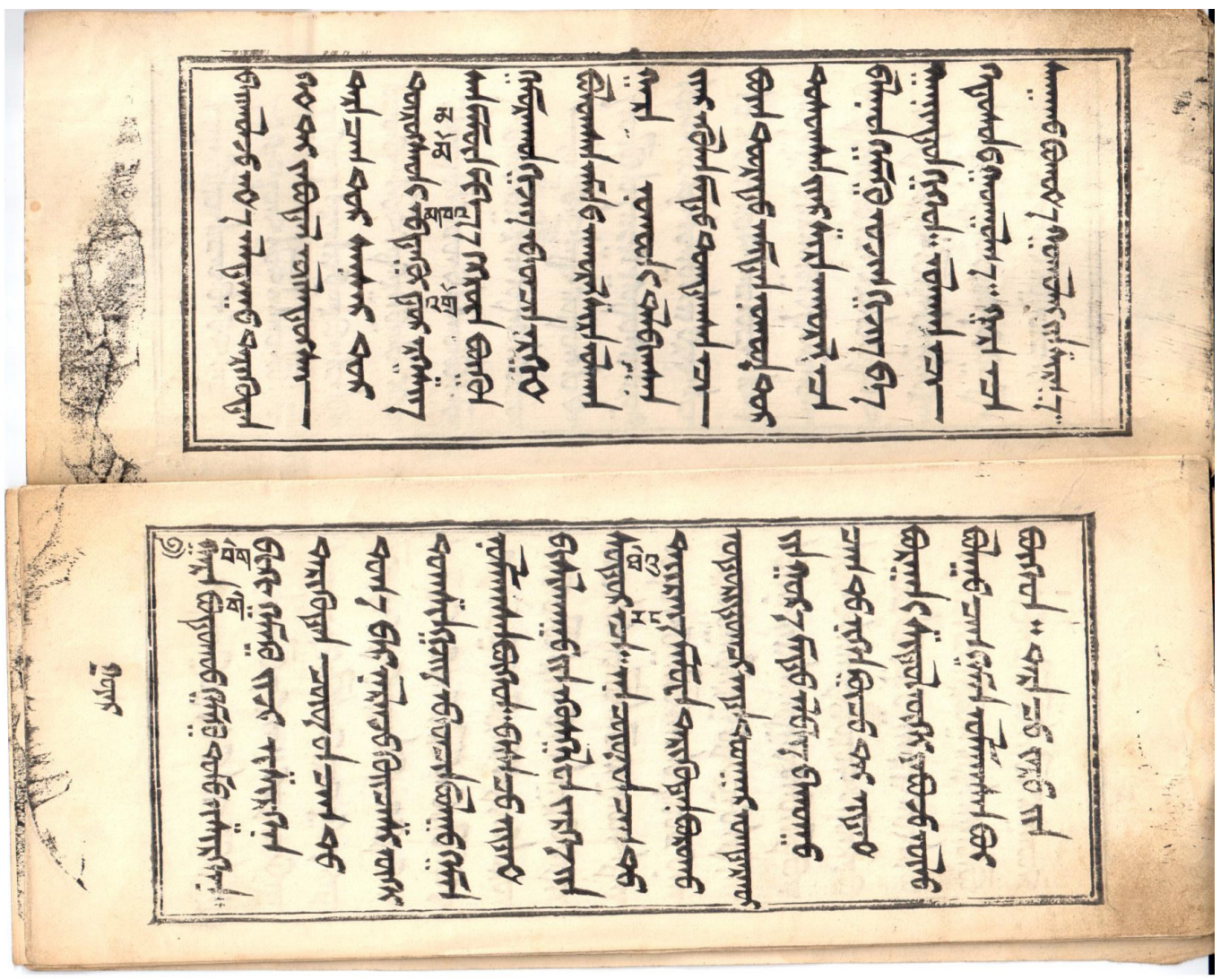

Фото 2. Фотокопия листов 1б-2а ксилографа $M-143$. Photo 2. A photocopy of pages $16-2$ a of xylograph $M-143$.

Первым в сборнике представлен фрагмент из 29-й главы известного медицинского трактата, хорошо известного под кратким названием «Лхантаб» (от тиб. Ihan thabs). Этот памятник известен также под кратким названием «Маннаг Лхантаб» (тиб. man ngag lhan thabs 'Дополнение к «Тантре наставлений»' ${ }^{\text {') }}$ (Болсохоева, 2009: Электр. ресурс). «Лхантаб» был составлен в качестве дополнения к 3-му тому «Чжудши» (Чжуд-ши. ..., 2001), но, по сути, является самостоятельным руководством по практической медицине (Болсохоева, 2009: Электр. ресурс; Санчжей Чжамцо, 1999). Его автором является известный тибетский буддийский деятель Дэсрид Санчжай-Чжамцо (Деси Сангье Гьяцо) (1653-1705), регент Далай-ламы V, крупнейший ученый своего времени, автор фундаментальных трудов по астрономии и астрологии, в том числе комментария к «Чжуд-ши», именуемого «Вайдурья-онбо» ('Голубой берилл’), истории тибетской медицины и др. Как отмечают исследователи, «Лхантаб» служил основным лечебным руководством для монахов-лекарей (эмчи-лам) Бурятии, практиковавших тибетскую медицину (Санчжей Чжамцо, 1999; Аюшеева, 2007: 9). Этот памятник был хорошо знаком не только бурятам, о чем свидетельствуют многочисленные образцы «Лхантабов» в фондах Центра восточных рукописей и ксилографов (ЦВРК) Института монголоведения, буддологии и тибетологии СО РАН (Ванчикова и др. 2011: 74), но и калмыкам. Одним из авторов русского перевода 30-й гл. «Лхантаба» является калмыцкий буддийский священнослужитель Дамбо-Даши Ульянов (1844-1913), лама Войска Донского, врач тибетской медицины (Перевод из тибетских медицинских сочинений Дже-ду-нинг-нор, 1902).

Особо хотелось бы сказать еще об одном буддийском памятнике, к тексту которого отсылает рассматриваемый сборник. Это хорошо известное сочинение из разряда дидактической литературы «Субхашита» (или «Драгоценная сокровищница изящных изречений»), автором которого является известный ученый, политический деятель XIII в. Сакья-пандита Гунга Джалцан (1182-1251). Примечательно,

${ }^{1}$ Под «Тантрой наставлений» имеется в виду классический медицинский трактат «Чжуд-ши» ('Четыре медицинские тантры’).

${ }^{2}$ Тиб. sDe srid sangs rgyas rgya mtsho. В отечественном востоковедении (тибетологии и монголоведении) передача тибетских имен на кириллице несколько отличается. Исторически сложилось, что российские тибетологи ориентировались на монголизированное произношение тибетских имен, которое сохраняется и в настоящее время, когда рассматриваются монгольские источники. При описании тибетских источников и реалий в современных материалах специалисты стали ориентироваться на нормы произношения литературного тибетского языка с опорой на лхаский диалект. 
что в коллекции старописьменных источников Калмыцкого научного центра РАН в г. Элисте имеются тексты «Субхашиты» на тибетском и ойратском языках (Музраева, 2015).

Из описания монгольской коллекции музея Тувы, выполненного монголоведом А. Г. Сазыкиным, следует, что последними в указанном сборнике представлены сочинения Джанджа-хутухты РолбиДорджэ и Ёндзин Еше Джалцана. Из примечаний к указанной выше публикации ее автор показывает, что речь идет о двух разных авторах, чьи труды цитируются (Sazykin, 1996: 48).

Предпоследний из приведенных в списке фрагментов представляет собой краткое изложение, скорее тезисное изложение мысли о принятии обета светскими лицами, сделанное Джанджа Ролби-Дорджэ, известным буддийским иерархом времен китайской империи Цин (1644-1912) - Джанджа-хутухты ${ }^{1}$ II Ролби-Дорджэ (1717-1786) (Успенский, 2011: 112-116). Завершают ксилографический сборник слова разъяснений относительно принятия и нарушения однодневного обета, данных учителем по имени Ёндзин Еше Джалцан. На наш взгляд, этим наставником может быть следующий в линии преемственности Джанджа-хутухт - Джанджа-хутухта III Ешей-Данби-Джалцан (1787-1846) (Успенский, 2011: 18, 105, 117).

В данной работе мы представляем полный текст данного сборника в виде транслитерации и перевода на русский язык с комментариями.

\section{Транслитерация текста}

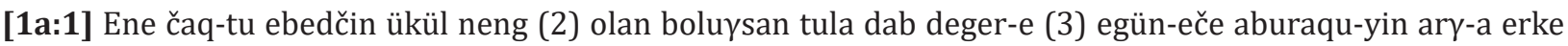
(4) ügei olqu keregtei tula: ebedčin (5) olan boluysan-u učir siltayan-i (6) öčüken tedüi ilerkeyilebesü: (7) em-ün sudur lhan tabs \{lhan thabs\}-un (8) qorin yisüdüki kij̄ig-un bölüg-|eče yerü-yin kümün-nügüd tabun (10) ǰaүun-u

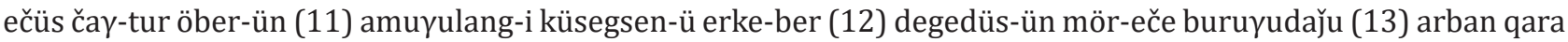

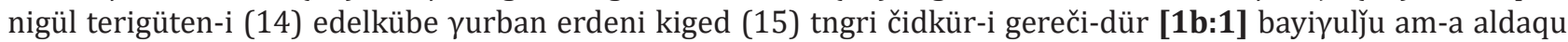
terigüten (2) gem-tei yabudal üyledügsen (3) tere ča $\gamma$-tur sansar-tur (4) törügsed-i ebdeküi-dür erkešig|sen mamô mka-a agro \{ma mo mkha' 'gro\} bükün (6) kimurayad kiǰig ebedčin erkim (7) boluүsan aman-u ayural šira ulayan

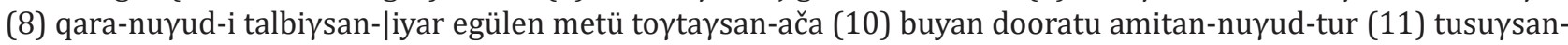

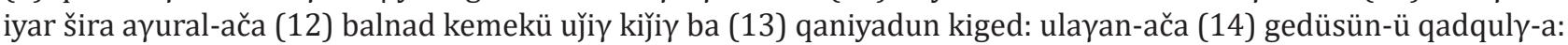

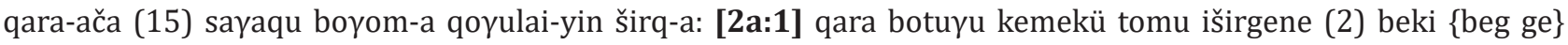

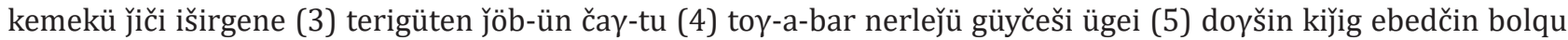

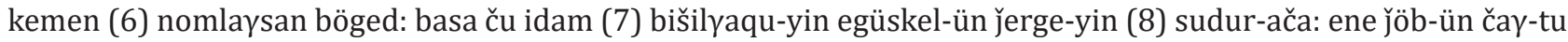

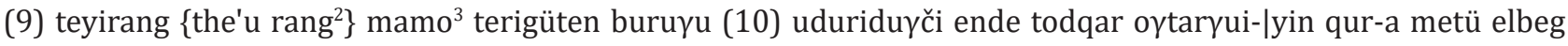

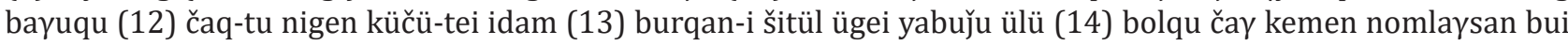
(15) böged: tere ču yerü-yin [2b:1] qara ger ten-ü sitükü idam (2) anu Otači: Ary-a Balo: (3) Dar-a eke terigüten

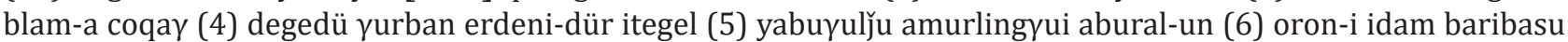
küčütei (7) idam burqan anu tere bolumui: (8) ende todqar olan boluysan učir (9) anu jöb-ün čay bolqu tutum (10) amitan-u nom-du qarsilaqu buruүu (11) yabudal ulam yekedegsen-iyer nasun (12) buyan ulam doroyitaysan-u

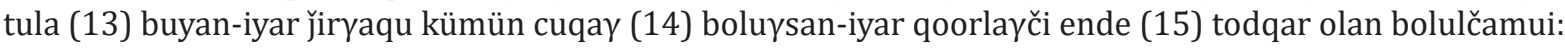

[3a:1] saskya \{sa skya ${ }^{4}$-yin sayin nomlal $\{\text { legs bshad }\}^{5}$-ača: ene (2) temečel-ün ča $\gamma$-tu ǰyun kümün-ü (3) dotur-ača nigen tegüs buyan-tai (4) kümün cuqay kemen nomlaysan bui (5) böged: teyimü bolbaču ene (6) šasin

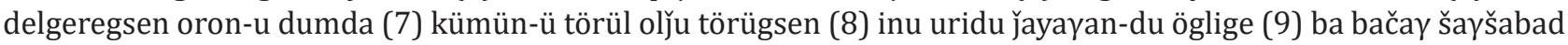

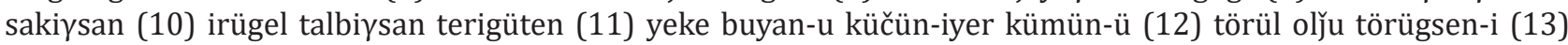

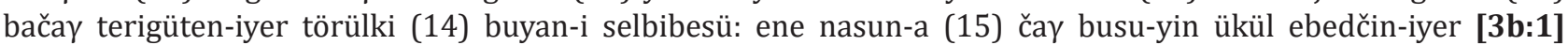

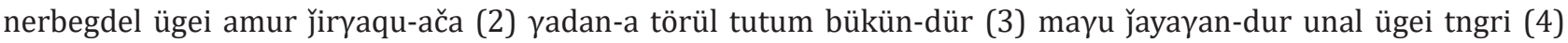

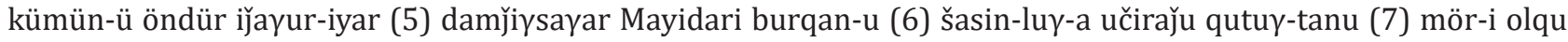

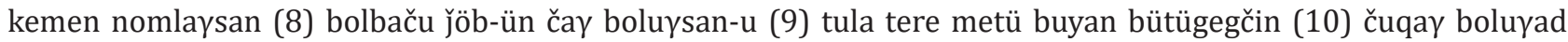

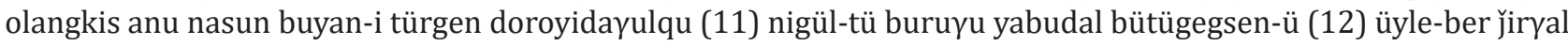

\footnotetext{
${ }^{1}$ Джанджа-хутухта (чжанчжа-хутухта) - так именовали буддийских святителей, чья резиденция находилась в Пекине; он считается воплощением грозного буддийского божества-хранителя Демчога (от тиб. bde mchog 'высшее счастье') (Рерих, 1985: 263-264). Другое имя этого же божества Самвара (Чакрасамвара).

${ }^{2}$ the'u rang = thebs rang - класс демонов (Das, 1902: 588).

${ }^{3}$ та то - разновидность злых демонов (Das, 1902: 949).

${ }^{4} s a$ skya - зд. речь идет о Сакья-пандите Гунга Джалцане.

${ }^{5}$ legs bshad - это сокращенное тибетское название знаменитого труда сакьяского иерарха, которое более известно под санскритским наименованием «Субхашита».
} 


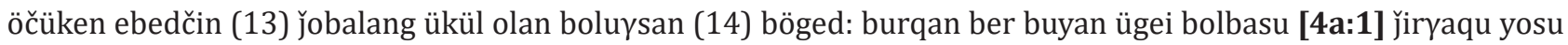

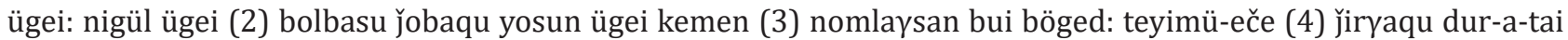
bolbasu (5) jobalang ireküi-yin urida nigül (6) kilinče arilyaqu ba buyan (7) quriyaqu keregtei tula burqan (8) ber qara gerten-dür šasin-u (9) qubiyari-ača buyan quriyaqu (10) kilinče arilyaqu-yin degedü (11) ene mön kemen edür-ün bača -un (12) sanvar qayiralaysan bayina:

(13) Lcangskiy-a Rolbiy Rdorji \{lcang skya rol ba'i rdo rje\}-yin (14) gegen-ü jarli $\gamma$-ača: qar-a ger|ten $\gamma$ urban

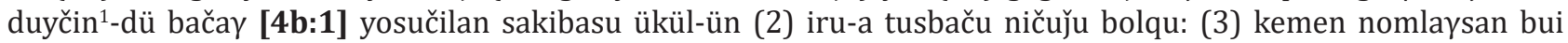
böged: yongs (4) aJin Yišis Rkyalmcan \{yongs 'dzin ye shes rgyal mtshan\}-u gegen-eče: (5) basa yosučilan sakiqu

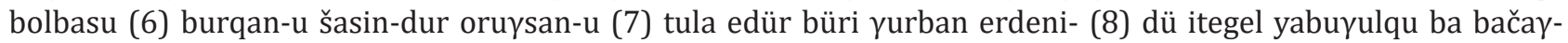
un (9) üy-e-dü arban qar-a nigül-eče (10) angqan-u dörben ündüsün ba (11) dörben gešigün-i tebčikü-yin (12)

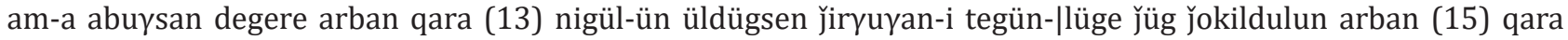
nigül-i bača $\gamma$-un üy-e-dü [5a:1] tebčikü yosutai tula: tedeger (2) arban qara nigül inu bey-e-ber (3) üyledkü ami

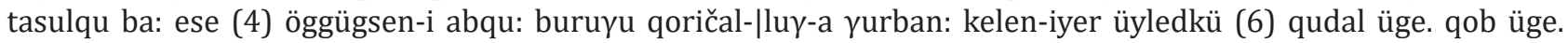
širügün (7) üge. ǰaliqai üge dörben (8) bolai: sedkil-iyer üyiledkü busud-|un ed tavar-tu qomuүalǰaqu (10) sedkil: busud-tu qoorlaqu (11) sedkil: buyan nigül-i itegekü ügei (12) buruүu üǰel böged qamtu arban (13) bolai: ǰöbün ča -un amitan edeger (14) nigülüd-i ene törül-tegen (15) kibesü mamô mka-a gro \{ma mo mkha' 'gro\}-yin

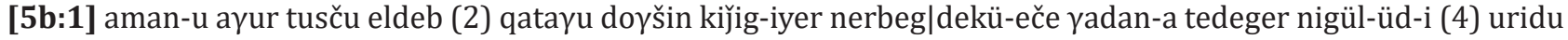
törül-tegen kigsen üyileyin (5) ür-e deger-e nemeri selbilte (6) boluүsan-iyar türgen bolbasuraǰu (7) ebedčin ükül

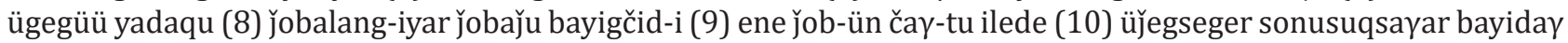
(11) tula bačaq sakiqu büri-dü (12) arban qar-a nigül-i büridken (13) toүalaǰu tedeger-eče ali bolqu (14) nigen-i kigsen bolbasu ǰobalang-un (15) köröngge ene aүsan bayina kemen [6a:1] kigsen-degen qoor-a idigsen metü (2)

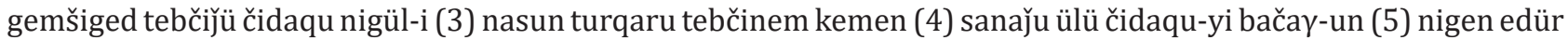

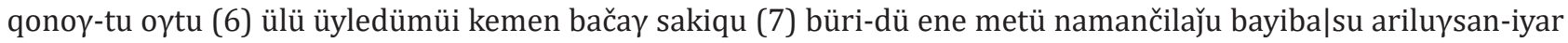
uridu-yin üyleyin (9) kilinče tüydker-iyer ebedčin (10) ǰobalang edlekü ba ene nasun-u (11) gem aldal-un üyile-ber

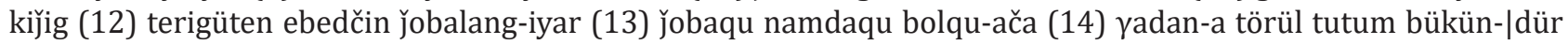

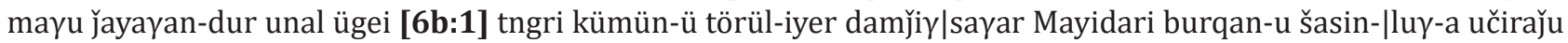

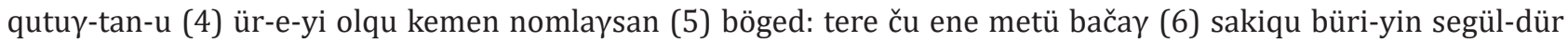

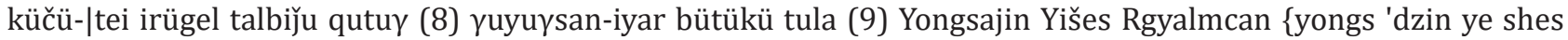

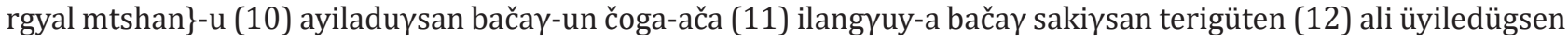

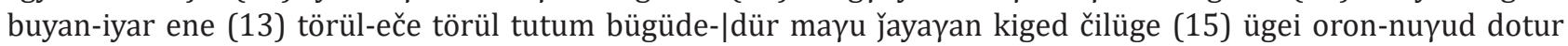
nigen [7a:1] gšan tedüi ču ülü oyiratuyad (2) nayman čilüge arban učiral (3) büridügsen sayin bey-e-yi ürgüly̌i (4)

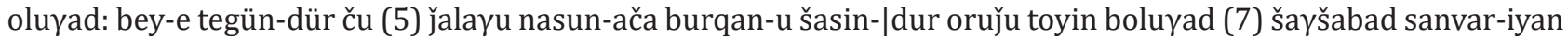

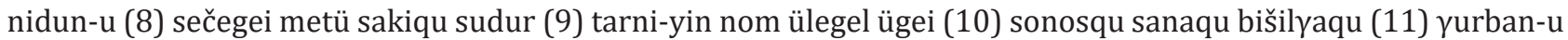
egüden-eče angqarun (12) abču bodisadu-a-yin arban oron (13) tabun mör bügüde-yin ečüs-tür (14) kürüged:

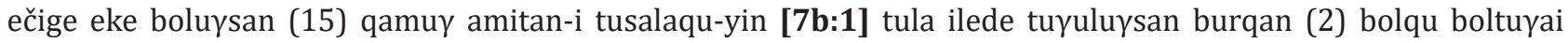

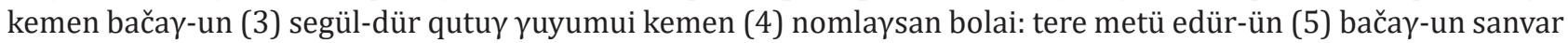

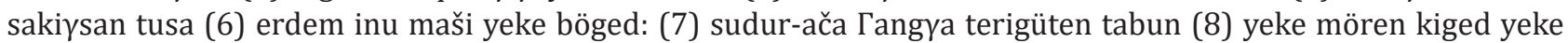

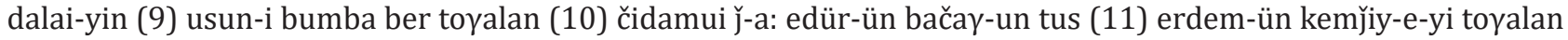

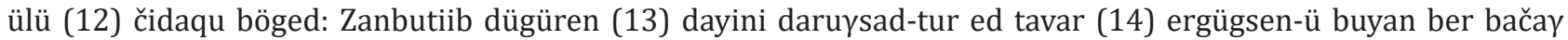

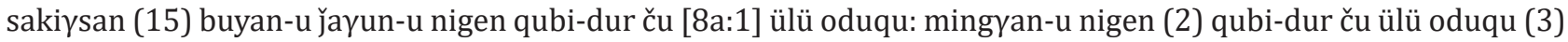

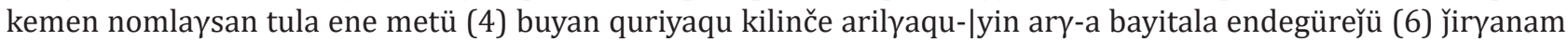
kemen nasun buyan-i (7) türgen baraqu-yin siltayan-i (8) üyledügsen-iyer ene nasun-a (9) eldeb ǰbalang-iyar

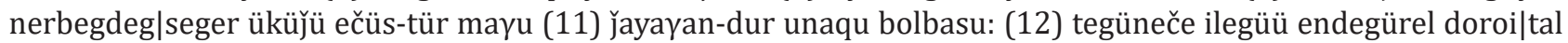

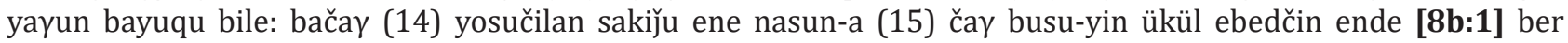
nerbegdel ügei ečüs qoyitu (2) törül tutum bükün-dür maүu (3) jayayan-dur unal ügei tngri (4) kümün-ü öndür

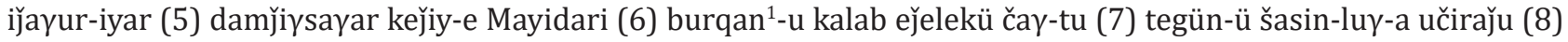

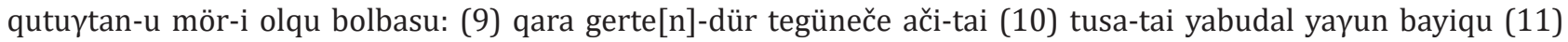

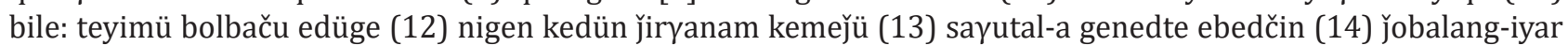

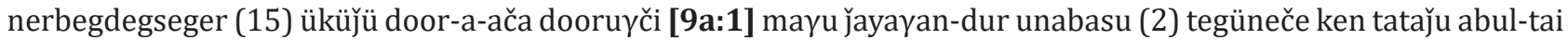

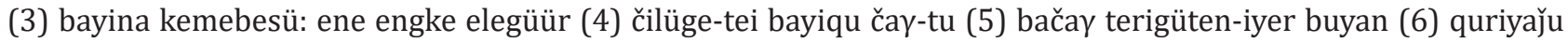

\footnotetext{
${ }^{1}$ Дуйцэн (от тиб. dus chen букв. ‘великое время’) - день, когда Будда, пребывавший в медитации под деревом бодхи, достиг просветления. Согласно мифологии, именно в этот день Будда был рожден, а также погрузился в нирвану, что признается большинством буддийских школ. Этот день приходится на 15-й день, полнолуние 4-го лунного месяца (Сага Дава), который выпадает на конец мая - начало июня согласно григорианскому календарю.

2 Будда Майтрейя - грядущий Будда.

${ }^{3}$ gürüm от тиб. sku rim 'религиозная церемония, религиозный обряд’ (Рерих, 1983: 168-169).
} 
НОВЫЕ ИССЛЕДОВАНИЯ ТУВЫ

www.nit.tuva.asia

\section{THE NEW RESEARCH OF TUVA}

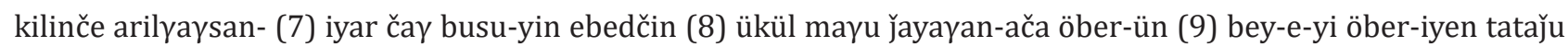

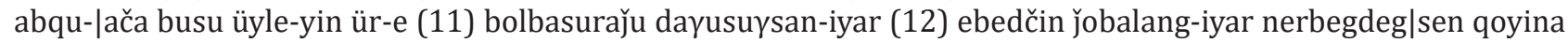
buyan bütügejü tataqu (14) čidal ügei bolumui: üyle-yin (15) ür-e-yin ebedčin-dü em ba [9b:1] gürüm³ tusa ügei

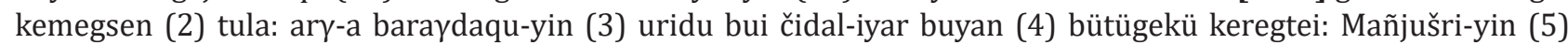

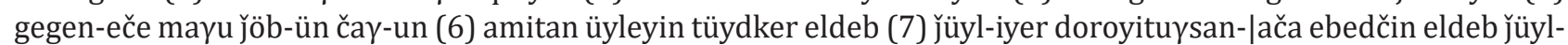

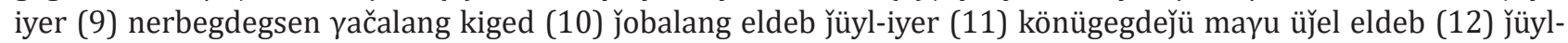

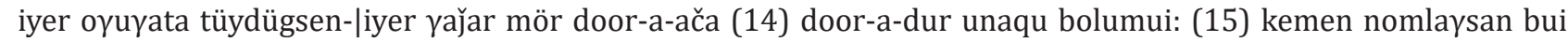
böged: [10a:1] teyimü-eče ene nasun-ača (2) bačaq terigüten buyan bütügegsen-ü (3) üyle-ber amur jiryaysayar (4) burqan bolqui kürtele tngri (5) kümün-ü amuүulang amsaqu ba: (6) ene nasun-ača nigül kigsen-ü (7) üyle-ber

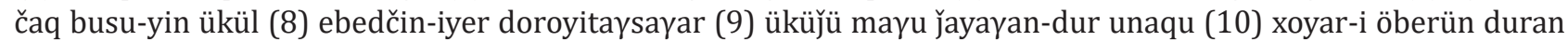

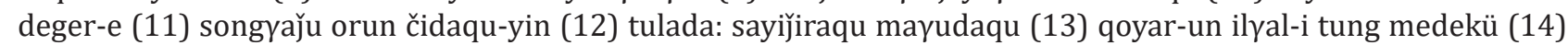

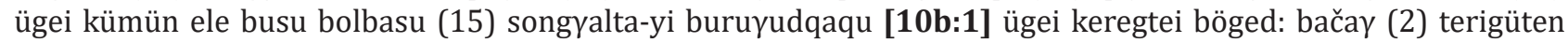
yerü buyan bütüge[kü]-du (3) ürjill-tei čaq anu caq anu: (4) ridi qubilyan sara-yin nigen (5) sine-eče arban tabun kürtele (6) kiged: qabur-un segül sara-yin (7) sine-yin nayman ba arban tabun (8) qoyar: jun-u nigen sara-yin (9) sine-yin nayman ba arban tabun-|nuүud yeke čaq mön-ü tula (11) aliba buyan bütügebesü abum (12) örčikü kemen nomlaysan böged: (13) edeger bačay sakiqu yosu ba (14) tusa erdem kiged buyan (15) bütügekü-yin ürjilge-

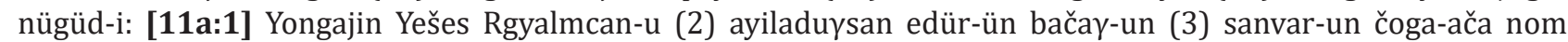

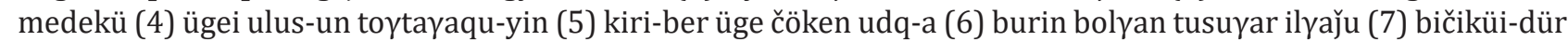

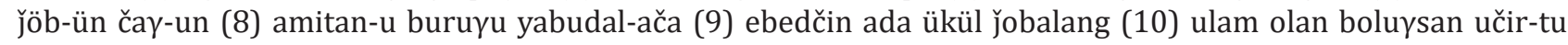

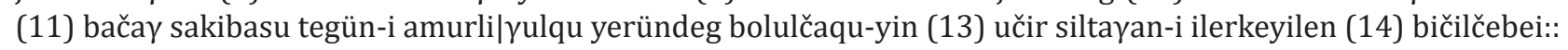

\section{Перевод}

[1a:1] В это время, когда неимоверно увеличилось число болезней и смертей, поскольку не оказалось способа и возможности тотчас же спастись от этого и возникла необходимость найти их, если вознамериться немного прояснить причину и обстоятельства болезней, то согласно 29-й главе «О простудных болезнях ${ }^{1} »$ лечебной (медицинской) сутры «Лхантаб», обычные люди в то время, когда заканчивается пять столетий, в силу того, что желают собственного благоденствия, сходят с пути наивысших, предаются десяти черным грехам, делают [1b:1] свидетелями Три драгоценности, а также тенгриев, злого духа (дьявола), совершают неблаговидные деяния, начиная с того, что дают обещание. В это время все дакини ма-мо ${ }^{2}$, обладающие властью истреблять всех рожденных в этой сансаре, приходят в возмущение, тем, что словесным гневом, [вызывающим] эпидемии, насылают желтое, красное и черное, когда подобно облаку успокаиваются, достигают (настигают) живых существ, обладающих малой добродетелью, от желтого происходят такие болезни, как балнад ${ }^{3}$, неизлечимые хронические болезни и кашель, от красного - колющие боли (колики) во внутренностях, от черного - нарыв, болезни горла, [2a:1] такие, как черная оспа, простуда (насморк, кашель), беки ${ }^{4}$ beg ge\} и другие. В зловредные времена придут эпидемии, которые невозможно исчислить, - так было проповедано.

Также из Сутры о пробуждении почитания идама ${ }^{5}$ [следует, что] в это время бедствия страшные демоны во главе со злыми демонами в то время, когда тех, кто ведет к неправедному, здесь станет очень много, подобно дождю, когда будут жить, не почитая какого-то сильного идама-будду, неподобающее время - так проповедал. [2b:1] Идамы, в которых следует верить простым мирянам, - это Отачи ${ }^{6}$, Арьябала ${ }^{7}$, Дара Эхэ ${ }^{8}$. Приняв прибежище в наивысших Трех драгоценностях и в ламе (учителе), если станут почитать идамов в [качестве] места спасения, то это и будут всесильные будды-идамы. Поскольку здесь появилось множество препятствий, всякий раз, когда будет наступать время зла, по мере того как станет все больше неправедных деяний, препятствующих живым существам [обращаться к] вере, поскольку еще больше сократились срок жизни и добродетель, стало мало людей, которые бы благоденствовали добродетелью, здесь появилось очень много препятствий преград (препон), наносящих вред.

\footnotetext{
${ }^{1}$ Тиб. cham ра (Санчжей Чжамцо 1999: 94-98).

${ }^{2}$ Согласно тексту «Лхантаб» в переводе А. Кособурова, «Демоны: “странствующие по небу” [демоны класса] ма-мо, “подстрекая” друг друга, возбуждаются и вызывают появление болезней ...» (Санчжей Чжамцо, 1999: 5-6).

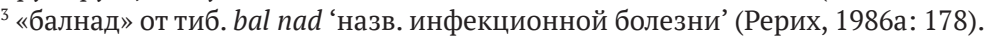

${ }^{4}$ от тиб. beg ge ‘корь' (Рерих, 1986а: 194).

${ }^{5}$ идам (тиб. yi dam) - зд. в значении «божество-хранитель»; др. значение ‘почт. обет; обещание, слово' (Рерих, 1986b: 247-248).

${ }^{6}$ Отачи - монгольский эквивалент имени Бхайшаджья-гуру (Будды врачевания, медицины).

${ }^{7}$ Арьябала - Авалокитешвара.

${ }^{8}$ Дара Эхэ - богиня Тара.
} 
[3a:1] Из наставлений Сакья-пандиты «Легшад»: В это время состязательности среди ста человек очень редко найти одиночку, [обладающего] совершенной добродетелью, - так проповедано. Хотя это и так, то, что получили рождение людьми в стране, в которой распространилось Учение, те, кто в предшествующем рождении произнесли благопожелание о том, чтобы соблюдать обет и совершать подношения, в силу великой добродетели обрели рождение людьми. Если обетами и прочим приумножить изначальную добродетель, помимо того, что в этой жизни будешь пребывать в мире и счастье, не подвергаясь болезням и смертям, в каждом перерождении не получая ${ }^{1}$ неблагоприятные рождения, последовательно обретая высокое рождение тенгрием и человеком, повстречавшись с Учением Будды Майтрейи, встанут на путь святых, - так хотя и было проповедано, поскольку настало время зла, подобных тому практикующих добродетель стало мало, большинство своими деяниями, совершая неправедные, греховные поступки, скорейшим образом сократили срок жизни и добродетель, в силу совершения неправедных деяний приумножились болезни, страдания и смерти. Будда проповедал: «Если не станет добродетели, [4a:1] не будет основания² для благоденствия». Исходя из этого, если имеешь желание благоденствовать, необходимо до наступления страданий избавиться от грехов и прегрешений и накапливать добродетель. Поскольку так, Будда даровал наставление, говоря, что наивысшим очищением от грехов и стяжанием добродетели в отношении веры для мирян ${ }^{3}$ воистину является обет принятия однодневного поста.

Из наставлений сиятельного (гэгээна) Джанджа Ролби Дордже. «Если миряне будут соответствующим образом [4b:1] соблюдать пост (воздержание) в течение трех [дней] дуйцэнг, даже если настигнет признак смерти, смогут избежать», - так наставлял.

Сиятельным (гэгээном) Ёндзин Еше Джалцаном было проповедано: «Если соблюдать [обет] подобающим образом, поскольку обратился в веру (Учение) Будды, помимо того, что дашь слово ежедневно принимать прибежище в Трех драгоценностях, в период поста будешь воздерживаться от совершения десяти греховных деяний - первых четырех основных и четырех второстепенных, шесть из совершенных десяти грехов соизмеряя с ними, в дни дуйцэнг должен отринуть десять грехов; [5a:1] в числе этих десяти грехов: совершаемые телом - убийство, отнятие того, что не принадлежит, вместе с похотью три [вида]; совершаемые изустно - ложные слова, клевета, резкие слова, вместе с коварными лживыми словами четыре [вида]; совершаемые мысленно - корыстные мысли по отношению к чужому имуществу, мысль навредить другим, неверие в добродетели и грехи, неправедные воззрения - все вместе [составляют] десять. Если живые существа этого зловредного времени станут совершать грехи в этом перерождении, то [их] настигнет словесный гнев злой дакини; [5b:1] помимо того, что подвергнутся всевозможным страшным, суровым эпидемиям, в силу того, что грехи становятся дополнением к плоду деяний, совершенных в прошлых рождениях, [который] быстро созревает, страдают от болезней, смертей и нищеты; поскольку они в это злобное время достоверно распознают таких и слышат [о них], всякий раз, когда держат пост, подсчитывают десять черных грехов, если был совершен хотя бы один из них, с мыслью ${ }^{4}$, что это и есть семена страданий, [6а:1] испытывая сожаления от того, что совершили, как если бы проглотили яд, решив на всю жизнь отказаться от грехов, от которых способны отказаться, - думая так, но не [имея] сил осуществить, если всякий раз в течение одного дня соблюдения поста подобно тому молиться, то очистишься, помимо того, что станешь меньше испытывать страданий изза грехов и препятствий прежних деяний, из-за порочных деяний этого срока жизни страдать от болезней, в том числе от эпидемий, помимо этого, в каждом перерождении не «упадешь» в неблагоприятные рождения, [6b:1] а получая рождения попеременно тенгрием или человеком, повстречавшись с Учением Будды Майтрейи, обретете плод святых», - так проповедал. Поскольку он также, подобно этому, всякий раз по окончании поста возносил действенное благопожелание, испрашивая святости и исполнял, из чоги (обряда соблюдения) поста, преподанной Ёндзин Еше Джалцаном, в особенности те, кто соблюдают пост, в силу любой накопленной добродетели, начиная с этого перерождения в каждом рождении не приблизившись даже на одно [7a:1] мгновение к неблагоприятному рождению или к месту (стране), где испытывают мучения, постоянно обретая благоприятное тело, преисполненное

\footnotetext{
${ }^{1}$ букв. 'не низвергаясь в неблагоприятные перерождения'.

${ }^{2}$ зд. букв. 'не будет закона'.

${ }^{3}$ зд. 'хар гертен’.

${ }^{4}$ букв. 'говоря’.

${ }^{5}$ т. е. 'не будешь получать'.

${ }^{6}$ зд. 'став тойном'.

${ }^{7}$ т. е. 'с позиций'.
} 
НОВЫЕ ИССЛЕДОВАНИЯ ТУВЫ

www.nit.tuva.asia

восемью свободами, десятью приобретениями, [пребывая] в этом теле, с раннего возраста проникшись Учением Будды, став монахом 6 , приняв во внимание всеохватно из трех врат ${ }^{7}$ слушания, осмысливания (обдумывания) и размышления (созерцания) учение сутр и дхарани (тарни) о том, как следует хранить как зеницу ока свои обеты и нравственные принципы ${ }^{1}$, достигнув в конечном итоге ${ }^{2}$ десяти стран, пяти путей бодхисаттвы, ради того чтобы оказать помощь всем живым существам, которые являлись отцом и матерью, [7b:1] да станете Победоносными Буддами! - сказав так, по окончании поста испросите святости, - такими словами наставил. Подобно тому, польза и заслуга (добродетель) от соблюдения однодневного обета очень велика. Из сутр [следует, что] вместилище вод великого океана и пяти великих рек во главе с Гангом можно определенно сосчитать. Меру определенной заслуги (пользы) от однодневного обета нет возможности сосчитать. Добродетель от того, что сделал подношение вещами (т. е. чем-то материальным) архатам ${ }^{3}$, заполнившим Замбутиб, [8a:1] не сравнится даже с одной сотой доли добродетели от того, что соблюдал обет, не сравнится даже с одной тысячной доли добродетели, поскольку было так проповедано, в то время как существует подобный этому способ стяжать добродетель и очиститься от грехов, заблуждаясь, говоря, что [желаешь] блаженствовать, тем, что создаешь причину быстрого исчерпания добродетели этого срока жизни, в этой жизни подвергаясь многочисленным страданиям, погибаешь и в конечном итоге обретаешь неблагоприятное рождение. Может ли быть какое-то иное, еще большее заблуждение и падение? Соблюдая обет соответствующим образом, в этой жизни [8b:1] не подвергаясь безвременным болезням и смерти, в каждом последующем рождении не получая неблагоприятного рождения, получая попеременно высокое рождение человеком или тенгрием, в то время, когда наступит калпа (кальпа) Будды Майтрейи, повстречавшись с его Учением, обретешь путь святых, что может быть более славным и полезным делом для мирян! Хотя [дело обстоит] так, сейчас те некоторые, в то время как жили с мыслью о счастье, внезапно подвергаясь мучениям от болезней и страданий, умирают и, когда низвергаются в самое низкое из низших [9а:1] неблагоприятных рождений, если спросить, кто способен вытянуть оттуда? - В то время, когда [пребываешь] в мире, когда свободен, накопив добродетель обетами, очистившись от грехов, только сам собственными силами вытянешь себя ${ }^{4}$ из плохой участи с безвременными болезнями и смертями; когда полностью созреет плод иных деяний, после того как испытаешь мучения от страданий и болезней, не будет сил творить добродетель и вытянуть. Поскольку было преподано, что при болезни плода деяний бесполезны лекарства и [9b:1] религиозные обряды (гурэм), до того как исчерпаются возможности, изо всех имеющихся сил следует накапливать добродетель.

Сиятельный Манджушри проповедал, что в силу того, что живые существа плохого неблагополучного времени самыми разными изобилующими препонами деяний пришли в упадок, стали терзаемы многими болезнями, их стали преследовать горести и страдания, а поскольку стали испытывать препятствия от многочисленных неправедных воззрений, то будут низвергаться в самые низкие из низших земель и пути, - так наставлял. [10a:1] Поскольку так, во имя того, чтобы иметь возможность свободного выбора и вступления на один из двух [путей]: начиная с этой жизни совершая деяния добродетели в первую очередь ${ }^{5}$ с принятия обета, живя в спокойствии, вплоть до того как станешь Буддой, испытывать блаженство тенгриев и людей, либо начиная с этого срока жизни, в силу совершенных грехов приходя в упадок от безвременных болезней и смертей, умирая, получать неблагоприятное рождение. Если не являетесь такими людьми, которые совершенно не понимают, в чем разница между тем, когда становится лучше, и тем, когда становится плохо, то следует не ошибиться в выборе, [10b:1] а также благодатным временем для того, чтобы творить обычную добродетель во главе с обетом, [является время] с первого дня месяца волшебных превращений 6 до пятнадцатого дня, а также с восьмого числа последнего весеннего месяца по пятнадцатый день, с восьмого дня первого летнего месяца и пятнадцатое - это воистину «великое время»7 если совершать любого рода добродетель, она увеличится в сто тысяч раз, - так проповедал. Эти правила соблюдения обета, приумножения заслуг и

\footnotetext{
${ }^{1}$ Согласно сочинению «Бодхичарья-аватара» («Путь бодхисаттвы») Шантидевы, «Что бы ни совершил я / В омрачении и по незнанию, / Будь то деяния, порочные по своей природе, / Или нарушенные обеты, - / Во всем этом я смиренно / Сознаюсь пред Покровителями» (Шантидева, Электр. ресурс: 15), из чего следует, что под порочными деяниями понимаются 1) деяния, пагубные по своей природе, и 2) деяния, связанные с нарушением обета. Эта мысль озвучена и в данном сборнике текстов.

${ }^{2}$ букв. 'в конце всего'.

${ }^{3}$ букв. 'подавившим врагов'.

${ }^{4}$ зд. букв. 'свое тело'.

${ }^{5}$ зд. букв. 'во главе с принятием обета'.

${ }^{6}$ зд. речь идет о чудесах, проявленных Буддой.

${ }^{7}$ под «великим временем» понимаются дни дуйцэн, см. прим. 1 на стр. 144.
} 
добродетели [11a:1] были выписаны, из обряда (чога) однодневного обета, изложенного Ёндзин Еше Джалцана, в соответствии с той мерой, особо различая, чтобы могли усвоить люди, не сведущие в Учении, когда слов мало, а смысл их совершенен. Когда в неблагоприятное время из-за неправедных поступков живых существ еще более прибавилось болезней, злых демонов, смертей и страданий, для того чтобы соблюдение обета стало противоядием, успокаивающим все это, проясняя причину и основание этого, записали.

\section{Заключение}

Таким образом, рассмотренный текст ксилографа на монгольском языке - это лишь малая часть того богатства, которым располагает Национальный музей Республики Тыва.

Компоновка этого сборника свидетельствует о высокой эрудиции его составителя. Хотя его имя эксплицитно не указано в тексте, имеется лишь косвенное указание на то, что текст составлен не одним пишущим, а при участии кого-то еще.

Рассмотренный сборник позволяет пролить свет на принципы использования известных сочинений при разъяснении разного рода положений буддийской доктрины. И это выводит нас к такой малоизученной области буддологических исследований, как комментаторская литература.

То, что в тексте присутствует аппеляция к верующим из числа светских последователей Учения Будды, демонстрирует значимость этой сферы проповеднической деятельности, практики буддийских священнослужителей в тувинской среде. Этот момент, а также то, что круг текстов и имен представителей высшей буддийской иерархии были известны не только тувинским буддистам, но и калмыцким, позволяют в дальнейшем проводить сопоставительный анализ письменных источников, имевших хождение в среде верующих в XIX-XX вв. и сохранившихся к началу XXI столетия в Калмыкии и Туве.

\section{СПИСОК ЛИТЕРАТУРЫ}

Аюшеева, Л. В. (2007) Роль тибетского врачевания в отечественной медицине (XVII-XX вв.) : автореф. дис. ... канд. мед. наук. М. 24 с.

Бичелдей, У. П. (2011) Собрание буддийских рукописей и ксилографов в фондах Национального музея Республики Тыва как памятники духовной культуры тувинского народа // Память мира: историко-документальное наследие буддизма. Мат-лы Межд. науч.-практ. конф. / отв. ред. В. В. Минаев. М. : РГГУ. 359 с. С. 228-233.

Болсохоева, Н. Д. (2009) «Лхантаб» - ключ к изучению клиники и терапии тибетской медицины в манба дацанах Центральной Азии [Электронный ресурс] // Синология.Py. URL: http://www.synologia.ru/a/«Лхантаб» (дата обращения: 27.02.2019).

Ванчикова, Ц. П., Жабон, Ю. Ж., Ринчинов, О. С., Елепов, Б. С., Шабанов, А. В. (2011) Коллекция медицинских текстов тибетского фонда Центра восточных рукописей и ксилографов (ЦВРК) Института монголоведения, буддологии и тибетологии СО РАН // Библиосфера. № 3. С. 72-76.

Донгак, А. С.-О. (2018) Легенды и устные рассказы об истории распространения буддизма в тувинском фольклоре // Вестник Калмыцкого института гуманитарных исследований РАН. № 1. С. 113-120.

Корнеев, Г. Б. (2016) Об ойратском старописьменном памятнике, посвященном традиции исполнения обряда «мацг» // Вестник Калмыцкого института гуманитарных исследований РАН. № 3. С. 201-208.

Мирзаева, С. В. (2018) Монгольская рукопись «Царя молитв-устремлений о благом пути» («Бхадрачарья») в Тувинском архиве // [Электронный ресурс] // Новые исследования Тувы. № 4. URL: https://nit.tuva.asia/nit/article/ view/814 (дата обращения: 27.02.2019). DOI: 10.25178/nit.2018.4.11

Музраева, Д. Н. (2011) О составе и содержании коллекций буддийских письменных памятников, сохранившихся в Калмыкии к началу XXI века // Память мира: историко-документальное наследие буддизма. Мат-лы Межд. науч.практ. конф. / отв. ред. В. В. Минаев. М. : РГГУ. 359 с. С. 233-240.

Музраева, Д. Н. (2015) Тексты «Субхашиты» на тибетском и ойратском языках из Научного архива КИГИ РАН» // Азия и Африка в меняющемся мире. XXVIII Межд. науч. конф. по источниковедению и историографии стран Азии и Африки», 22-24 апреля 2015 г.: Тезисы докладов / отв. ред. Н. Н. Дьяков, А. С. Матвеев. СПб. : ВФ СПбГУ. 556 с. С. 247.

Перевод из тибетских медицинских сочинений Дже-ду-нинг-нор, гл. 91 и Хлан-таб, гл. 30. Лечения чумы, холеры и проказы. Штатного гелюна Дамбо Ульянова (1902). СПб. : Паровая Скоропечатня «Восток» М.М. Гутзац. 25 с.

Рерих, Ю. Н. (1983) Тибетско-русско-английский словарь с санскритскими параллелями : в 10 вып. М. : Наука. ГРВЛ. Вып. І. 378 с. 
Рерих, Ю. Н. (1985) Тибетско-русско-английский словарь с санскритскими параллелями : в 10 вып. М. : Наука. ГРВЛ. Вып. IV. 374 с.

Рерих, Ю. Н. (1986а) Тибетско-русско-английский словарь с санскритскими параллелями : в 10 вып. М. : Наука. ГРВЛ. Вып. VI. 372 с.

Рерих, Ю. Н. (1986b) Тибетско-русско-английский словарь с санскритскими параллелями : в 10 вып. М. : Наука. ГРВЛ. Вып. VIII. 311 с.

Санчжей Чжамцо (1999) : Практическое руководство по тибетской медицине Лхан-тхабс. Разделы га, нга, ча. Главы 15-47 : перев. с тиб. Улан-Удэ : Изд-во БНЦ СО РАН. 216 с.

Успенский, В. Л. (2011) Тибетский буддизм в Пекине. СПб. : Студия «НП-Принт». 368 с.

Чжуд-ши. Канон тибетской медицины (2001) / перев. с тибетского, предисл., прим., указ. Д. Б. Дашиева. М. : Восточная литература. 766 с.

Шантидева. Бодхичарья-аватара (Путь бодхисаттвы) / пер. Ю. Жиронкиной [Электронный ресурс] // Интернетбиблиотека буддийских текстов. URL: http://abhidharma.ru/A/Bodhissatva/Content/Bodhicharya-avatara.pdf (дата обращения: 21.02.2019).

Das, S. Ch. (1902) A Tibetan-English Dictionary. Calcutta : Bengal Secretariat Press. 1353 p.

Sazykin, A. (1996) The Collection of Mongolian Manuscripts and Xylographs in the Ethnological Museum of the Republic of Tuva in Kyzyl // Manuscripta Orientalia. Vol. 2. № 2. P. 44-49.

Дата поступления: 07.03.2019 г.

\section{REFERENCES}

Ayusheeva, L. V. (2007) Rol' tibetskogo vrachevaniya $v$ otechestvennoy meditsine (XVII-XX vv.) [The role of Tibetan healing in Russian medicine, 17th-20th centuries] : Thesis of Diss.... Candidate of Medical sciences. Moscow. 24 p. (In Russ.).

Bicheldey, U. P. (2011) Sobranie buddiyskikh rukopisey i ksilografov v fondakh Natsional'nogo muzeya Respubliki Tyva kak pamyatniki dukhovnoy kul'tury tuvinskogo naroda [Buddhist manuscripts and woodcuts in the collections of the National Museum of the Republic of Tuva as monuments of spiritual culture of the Tuvan people]. In: Pamyat' mira: istoriko-dokumental'noe nasledie buddizma [Memory of the world: the historical and documentary heritage of Buddhism]: Proceedings of an international conference / ed. by V. V. Minaev. Moscow, Russian State University for the Humanities. 359 p. Pp. 228-233. (In Russ.).

Bolsokhoeva, N. D. (2009) «Lkhantab» - klyuch k izucheniyu kliniki i terapii tibetskoy meditsiny v manba datsanakh Tsentral'noy Azii ["Lhantab" as the key to the study of the clinic and therapy of Tibetan medicine in manba datsans of Central Asia]. Sinologiya.Ru [online] Available at: http://www.synologia.ru/a/«Lkhantab» (access date: 27.02.2019). (In Russ.).

Vanchikova, Ts. P., Zhabon, Yu. Zh., Rinchinov, O. S., Elepov, B. S. and Shabanov, A. V. (2011) Kollektsiya meditsinskikh tekstov tibetskogo fonda Tsentra vostochnykh rukopisey i ksilografov (TsVRK) Instituta mongolovedeniya, buddologii i tibetologii SO RAN [Medical texts in the Tibetan collection at the Center for Oriental Manuscripts and Woodcuts (TsVRK) of the Institute of Mongolian Studies, Buddhology and Tibetology SB RAS]. Bibliosfera, no. 3, pp. 72-76. (In Russ.).

Dongak, A. S.-O. (2018) Legendy i ustnye rasskazy ob istorii rasprostraneniya buddizma v tuvinskom fol'klore [A history of Buddhism's dissemination in Tuvan folklore: Legends and oral narratives]. Bulletin of the Kalmyk Institute for Humanities of the Russian Academy of Sciences, vol. 35, issue 1, pp. 113-120. (In Russ.)

Korneev, G. B. (2016) Ob oiratskom staropis'mennom pamyatnike, posvyashchennom traditsii ispolneniia obriada «matsg» [On an Oirat written monument devoted to the tradition of 'matsg' ritual performance]. Bulletin of the Kalmyk Institute for Humanities of the Russian Academy of Sciences, vol. 25, issue 3, pp. 201-208. (In Russ.)

Mirzaeva, S. V. (2018) Mongol'skaia rukopis' «Tsaria molitv-ustremlenii o blagom puti» («Bkhadrachar'ia») v Tuvinskom arkhive [The Mongolian manuscript of the «Bhadracarya» (The King of Aspiration Prayers, The Aspiration for Noble Excellent Conduct) from a Tuvan archive]. The New Research of Tuva, no. 4 [online] Available at: https://nit.tuva.asia/nit/ article/view/814 (access date: 27.02.2019). DOI: 10.25178/nit.2018.4.11 (In Russ.)

Muzraeva, D. N. (2011) O sostave i soderzhanii kollektsii buddiiskikh pis'mennykh pamyatnikov, sokhranivshikhsya v Kalmykii k nachalu XXI veka [On the composition and content of the collections of Buddhist written monuments preserved in Kalmykia by the beginning of the 21st century]. In: Pamyat' mira: istoriko-dokumental'noe nasledie buddizma [Memory of the world: the historical and documentary heritage of Buddhism]: Proceedings of an international conference / ed. by V. V. Minaev. Moscow, Russian State University for the Humanities. 359 p. Pp. 233-240. (In Russ.).

Muzraeva, D. N. (2015) Teksty «Subkhashity» na tibetskom i oyratskom yazykakh iz Nauchnogo arkhiva KIGI RAN» [Texts of "Subhashita" in Tibetan and Oirat languages from the Scientific Archive of the Kalmyk Institute for Humanitarian Studies of the RAS]. In: Aziia i Afrika $v$ meniaiushchemsia mire [Asia and Africa in a changing world]. 28th International conference on source studies and historiography of Asian and African countries”, April 22-24, 2015: Abstracts. / ed. by N. N. Dyakov and A.S. Matveev. St. Petersburg, Faculty of Asian and African studies of the St. Petersburg State University. 556 p. P. 247. (In Russ.). 
Perevod iz tibetskikh meditsinskikh sochineniy Dzhe-du-ning-nor, gl. 91 i Khlan-tab, gl. 30. Lecheniya chumy, kholery $i$ prokazy. Shtatnogo gelyuna Dambo Ul'yanova [A Translation from Tibetan medical writings, Je-du-ning-nor, ch. 91 and Hlantab, ch. 30. Treatments for the plague, cholera and leprosy. By Staff geljun Dumbo Ulyanov] (1902). St. Petersburg, Steam Reprint "Orient" of M M. Gutzats. 25 p. (In Russ.).

Roerich, Yu. N. (1983) Tibetsko-russko-angliyskiy slovar's sanskritskimi parallelyami [A Tibetan-Russian-English dictionary with Sanskrit parallels]: in 10 issues. Moscow, Nauka. GRVL. Issue I. 378 p. (In Tib., Russ. and Engl.).

Roerich, Yu. N. (1985) Tibetsko-russko-angliyskiy slovar's sanskritskimi parallelyami [A Tibetan-Russian-English dictionary with Sanskrit parallels]: in 10 issues. Moscow, Nauka. GRVL. Issue IV. 374 p. (In Tib., Russ. and Engl.).

Roerich, Yu. N. (1986a) Tibetsko-russko-angliyskiy slovar' s sanskritskimi parallelyami [A Tibetan-Russian-English dictionary with Sanskrit parallels]: in 10 issues. Moscow, Nauka. GRVL. Issue VI. 372 p. (In Tib., Russ. and Engl.).

Roerich, Yu. N. (1986b) Tibetsko-russko-angliyskiy slovar's sanskritskimi parallelyami [A Tibetan-Russian-English dictionary with Sanskrit parallels]: in 10 issues. Moscow, Nauka. GRVL. Issue VIII. 311 p. (In Tib., Russ. and Engl.).

Sanchzhey Chzhamtso (1999) Prakticheskoe rukovodstvo po tibetskoy meditsine Lkhan-tkhabs. Razdely ga, nga, cha. Glavy 15-47. Perev. s tib. [A practical guide to Tibetan medicine Lhan-Thabs. Sections ga, nga, cha. Chapters 15-47]. Transl. from Tibetan. Ulan-Ude, Buryat Scientific Center SB RAS. 216 p. (In Russ.). Russ.).

Uspenskiy, V. L. (2011) Tibetskiy buddizm v Pekine [Tibetan Buddhism in Beijing]. St. Petersburg, NP-Print. 368 p. (In

Chzhud-shi. Kanon tibetskoy meditsiny [Zhud-shi. The canon of Tibetan medicine] (2001). Translation from Tibetan, preface, notes, indexes by D. B. Dashiev. Moscow, Vost. lit. Publ. 766 p. (In Russ.).

Shantideva. Bodkhichar'ya-avatara (Put' bodkhisattvy) [Shantideva. Bodhicharya-avatara (Path of Bodhisattva)] / transl. by Yu. Zhironkina. Internet-biblioteka buddiyskikh tekstov [online] Available at: http://abhidharma.ru/A/Bodhissatva/ Content/Bodhicharya-avatara.pdf (access date: 21.02.2019). (In Russ.).

Das, S. Ch. (1902) A Tibetan-English Dictionary. Calcutta, Bengal Secretariat Press. 1353 p. (In Tib. and Engl.).

Sazykin, A. (1996) The Collection of Mongolian Manuscripts and Xylographs in the Ethnological Museum of the Republic of Tuva in Kyzyl. Manuscripta Orientalia, vol. 2, no. 2, pp. 44-49. 